\begin{tabular}{|l|l|l|}
\hline \multicolumn{2}{|c|}{ PublisherInfo } \\
\hline \hline PublisherName & $:$ & BioMed Central \\
\hline \hline PublisherLocation & $:$ & London \\
\hline \hline PublisherImprintName & $:$ & BioMed Central \\
\hline \hline
\end{tabular}

\title{
Melatonin's action in the brain
}

\begin{tabular}{|l|l|l||}
\hline \multicolumn{2}{|c||}{ ArticleInfo } \\
\hline \hline ArticleID & $:$ & 5060 \\
\hline \hline ArticleDOI & $:$ & 10.1186 /gb-spotlight-20050210-02 \\
\hline \hline ArticleCitationID & $:$ & spotlight-20050210-02 \\
\hline \hline ArticleSequenceNumber & $:$ & 36 \\
\hline \hline ArticleCategory & $:$ & Research news \\
\hline ArticleFirstPage & $:$ & 1 \\
\hline \hline ArticleLastPage & $:$ & 3 \\
\hline \hline & & RegistrationDate : 2005-2-10 \\
\hline ArticleHistory & $:$ & OnlineDate \\
\hline \hline ArticleCopyright & $:$ & BioMed Central Ltd2005-2-10 \\
\hline \hline ArticleGrants & $:$ & \\
\hline \hline ArticleContext & $:$ & 130596611 \\
\hline \hline
\end{tabular}


Charles Q Choi

Email: cqchoi@nasw.org

Scientists have found the first instance of melatonin directly acting on a neuropeptide in the vertebrate brain, they reported February 7 online in $P N A S$.

"This suggests if melatonin can do this on one neuropeptide system, it could do it on other neuropeptide systems," coauthor George Bentley of the University of California at Berkeley told The Scientist.

In 2000, Kazuyoshi Tsutsui at Hiroshima University in Japan and colleagues discovered a neuropeptide dubbed $\mathrm{GnIH}$ that inhibited gonadotropin release, serving as the missing antagonist for gonadotropin-releasing hormone, the primary agonist controlling reproduction in vertebrates. In searching for regulatory mechanisms governing GnIH expression, the investigators noted melatonin was implicated in seasonal gonadotropin secretion.

To explore any link between melatonin and $\mathrm{GnIH}$, the researchers focused on quail, which are highly photoperiodic, and removed their major sources of melatonin, the eyes and pineal gland. They quantified expression of $\mathrm{GnIH}$ precursor mRNA via competitive polymerase chain reaction, measured $\mathrm{GnIH}$ concentration in the diencephalon through enzyme-linked immunosorbent assay, and measured melatonin in the diencephalon and plasma with radioimmunoassay.

GnIH mRNA and GnIH levels dropped significantly in birds in which circulating melatonin was removed, the researchers found. Melatonin replacement led to significant increases in GnIH mRNA and GnIH levels in a dose-dependent manner.

Melatonin is secreted at night in all vertebrates. To analyze the effect endogenous melatonin had, the researchers used male quail exposed to short-day and long-day photoperiods. They found that expression of diencephalic GnIH mRNA and GnIH increased significantly in short-day birds, as did testicular weight.

To identify the mode of melatonin action on GnIH expression, the researchers investigated the expression of melatonin receptor subtype Me1(1c) in the paraventricular nucleus in quail, one major region where $\mathrm{GnIH}$ is expressed. Partial quail Me1(1c) cDNA was cloned, and in situ hybridization revealed intense expression of Me1(1c) mRNA distributed in the quail paraventricular nucleus. Immunocytochemistry for GnIH revealed clear colocalization of the neuropeptide with Me1(1c) mRNA. Melatonin receptor autoradiography also revealed significant binding of melatonin in the paraventricular nucleus. Evidence for colocalization of GnIH with melatonin receptor subtypes Me1(1a) and Me1(1b) was inconclusive.

The investigators also cloned a homolog of GnIH from the brain of a Siberian hamster. Expression of that neuropeptide was also controlled by melatonin. "We suspect this system is extremely widespread," Bentley said.

"Directions from now include examining this system for agriculture, such as cattle and sheep, and for zoos. It's important for the basic understanding of reproduction in pretty much any vertebrate," said Martin Wikelski of Princeton University, who did not participate in this study. 
"It'd be interesting to look at owls, who hardly have any melatonin rhythm. Do they still use melatonin signals to regulate GnIH?" said Michaela Hau of Princeton University, who did not participate in this study. "I'm interested in the use of melatonin in birds in the tropics, who hardly ever shut reproductive activity down. The day lengths don't change much in the tropics."

"One of the big questions, particularly relating to humans, is how metabolism affects reproduction. With diseases like diabetes and anorexia, you see the reproductive system turned off. So these findings could help us understand if the reproductive system is shut down in response to altered nutritional signals because of an increase in GnIH within the brain," said Gregory Fraley of Hope College in Holland, Mich., who did not participate in this study.

While $\mathrm{GnIH}$ is encoded by one gene, that gene encodes a precursor polypeptide that is cleaved into three and possibly four mature polypeptides. "We know little about what the other GnIH-related peptides are doing," Bentley said. Furthermore, "the neurons that produce GnIH have fibers that spread as far back as the brainstem, going into multiple brain areas that control physiological and cognitive

processes. So, given that you also have these GnIH-related polypeptides in addition to GnIH, melatonin could have a multitude of downstream effects."

\section{References}

1. T. Ubuka et al., "Melatonin induces the expression of gonadotropin-inhibitory hormone in the avian brain." PNAS, published online February 7, 2005., [http://www.pnas.org/]

2. K. Tsutsui et al., "A novel avian hypothalamic peptide inhibiting gonadotropin release," Biochem Biophys Res Commun, 275:661-7, August 28, 2000.

3. Martin Wikelski, [http://www.princeton.edu/ wikelski/]

4. Michaela Hau, [http://www.princeton.edu/ hau/]

5. Gregory Fraley, [http://www.hope.edu/academic/biology/faculty/fraley.htm] 